\title{
Negaksjologie sfery publicznej. Społeczna anomia, apatia i atomia, czyli w kręgu mono(seo)kracji
}

DOI: http://dx.doi.org/10.12775/RF.2014.013

Porządki, w których się poruszamy, okazuja się porzadkami w trybie przypuszczajacym*.

Bernhard Waldenfels

Bożek wspólnoty umacnia swoją siłe przyciagania słabych tego światazrozumiaty jako ideologia wykluczonych, rozczarowanych i oczekujacych, [...] usprawiedliwiony jako protest ludzi cierpiacych z powodu wielkomiejskiego, zmechanizowanego i wykorzenionego życia**.

Helmuth Plessner

Któż jednak nie jest odmienny?***

Hans Mayer

\section{Dychotomie - ambiwalencje - polifonie}

Nim powiemy cokolwiek więcej w sygnalizowanej tytułem kwestii, wprzód trzeba się odnieść do samego tematu, rozwikłując, na ile to

* B. Waldenfels, Podstawowe motywy fenomenologii obcego, przeł. J. Sidorek, Oficyna Naukowa, Warszawa 2009, s. 15.

** H. Plessner, Granice wspólnoty. Krytyka radykalizmu społecznego, przeł. J. Merecki, Oficyna Naukowa, Warszawa 2008, s. 28.

*** H. Mayer, Odmieńcy, przeł. A. Kryczyńska, Warszawskie Wydawnictwo Literackie Muza, Warszawa 2005, s. 29. 
możliwe, a przynajmniej uczytelniając, zawarte w nim terminy, których obcość i tajemniczość - miejmy nadzieję - szybko ustąpią miejsca oswojeniu i jasności.

Termin „negaksjologie” powstał częściowo przez skojarzenie z terminem ",negatypy", utworzonym i spopularyzowanym przez Marcina T. Zdrenkę ${ }^{1}$. Najprościej mówiąc, co łatwo domniemać z samej konstrukcji słowa, termin "negaksjologie” oznacza dowolne (w naszym przypadku późnonowoczesne) negatywne aksjologie bądź aksjologie wartości negatywny ch - choć w szczegółach, gdy idzie o klasyfikacje negaksjologii - uznając wstępną swojskość i jasność terminu, pozwolę sobie pisać go dalej już bez cudzysłowu - sprawa wygląda nieco trudniej i bardziej złożenie.

Termin „,anomia” wydaje się na tyle dostatecznie rozpropagowany, zwłaszcza przez dyskurs socjologiczny, że nie wymaga on w tym miejscu wstępnego doprecyzowania. Właściwe dookreślenia nastąpią później. Przy okazji wyrażam nadzieję, że - wbrew skądinąd uzasadnionym obawom Mirosławy Marody i Anny Gizy-Poleszczuk, przedstawionym przez ni we Wprowadzeniu do Przemian więzi społecznych ${ }^{2}$, wielce pożytecznej nie tylko dla socjologów książki - posługując się tak klasycznym resp. dobrze znanym terminem, jak ",anomia", nie ryzykuję „»usypiania " potencjalnego odbiorcy", następującego zwykle wówczas, gdy każdemu wydaje się, że wie, o co autorowi chodzi, i zaczyna prześlizgiwać się nad tekstem ${ }^{3}$.

Termin „apatia” rodzi prima facie słuszne skojarzenia z antyczną refleksją moralną i nie ma bynajmniej w sposobie, w jaki go tu używam, śladu psychologicznego drenażu, któremu z czasem uległ.

Termin „atomia” ma, z kolei, wyobrażać następstwa procesu rozpadu tkanki społecznej, jej rozproszenia, rozparcelowania, rozwodnienia, rozbicia, destrukcji. I on, podobnie jak „,apatia”, słusznie łączy się w naszej pamięci ze starożytnością, lecz więzy te są znacznie luźniejsze, ograniczają się bowiem niemal wyłącznie do znaczenia wyprowadzonego z etymologii słowa. Zwykle mówi się o a to mi z a cji lub a to mi z mie politycznym - tym drugim określeniem posługuje się np. Charles Taylor ${ }^{4}$. Coraz częściej jednak rozszerza się jego znaczenie, wychodząc poza

1 Por. M.T. Zdrenka, Pewien kłopot z intersubiektywnościa wartości. Przyczynek do refleksji o negatywach, czyli o ogniskowaniu się negatywnych skojarzeń wartościujacych, w: Intersubiektywność, red. nauk. P. Makowski, TAiWPN Universitas, Kraków 2012, s. $165-168$.

2 Zob. M. Marody, A. Giza-Poleszczuk, Przemiany więzi społecznych. Zarys teorii zmiany społecznej, Wydawnictwo Naukowe Scholar, Warszawa 2004.

3 Ibidem, s. 9.

4 Por. Ch. Taylor, Źródła podmiotowości. Narodziny tożsamości nowoczesnej, przeł. M. Gruszczyński et al., oprac. T. Gadacz, Wydawnictwo Naukowe PWN, Warszawa 2001, s. 360-367. 
sferę polityki w kierunku społeczeństwa, co pozwala mówić o atomizacji lub atomizmie społecznym.

Czas wreszcie powiedzieć słowo o najbardziej chyba zagadkowo brzmiącym terminie "mono(seo)kracja”, z charakterystyczną znajdującą się pośrodku wyrazu sylabą „,seo", wtrąconą graficznie w nawias. Zabieg ten ma sugerować dwojakie znaczenie słowa. Pierwsze, uwzględniające ową sylabę, wskazywać ma na „-krację", a więc "formę rządów” sprawowanych współcześnie, tj. - najmniej precyzyjnie mówiąc, ale za to najbardziej zrozumiale - „w naszych czasach", sięgających w głąb XX wieku, a wytryskujących ze źródeł dziewiętnastowiecznych i trwających do chwili obecnej, sprawowanych przez "monose”, co ze starogrecka znaczy "samotnośćc pojedynczości. W duchu Emmanuela Levinasa tłumaczyłbym to jako imperializm jednostkowości, którego historię, logikę i stan faktyczny z takim znawstwem i wnikliwością jako „erę jednostki" opisuje Alain Renaut ${ }^{5}$, twierdząc, że oznacza ona przejście w filozofii i w ogóle w kulturze współczesnej od figury podmiotu do figury jednostki. Śmierć podmiotu nie jest zatem - jak mutatis mutandis chce tego Francis Fukuyama - końcem człowieka ${ }^{6}$, lecz co najwyżej końcem pewnej narracji o człowieku, pewnej - rzec można - heurezy antropokulturowej. Wraz z tą śmiercią bowiem dokonują się narodziny - lub właściwiej powiedzieć: inkarnacja jednostki - nowego typu człowieka; nowej lub tylko zmienionej, zniuansowanej, będącej zapewne po części rezultatem następującego po sobie biegu wypadków narracji, uprzywilejowującej skrajnie indywidualistyczną optykę. Trzymając się terminologii cielesnej - karnacyjnej, aczkolwiek dotyczącej ducha, zaryzykować można spostrzeżenie, że podmiot zreinkarnował w jednostkę.

W pierwszym znaczeniu zatem mono(seo)kracja oznacza przejście zarówno w filozofii, jak i moralności oraz w ogóle w całokształcie procesów kulturowych - z pozycji podmiotywistyczny ch ${ }^{7}$ na pozycje skrajnie indywidualistyczne, z wszystkimi tego konsekwencja$\mathrm{mi}$ - nie tylko psychosocjologicznymi, ale zwłaszcza aksjonormatywnymi.

Mono(seo)kracja przestaje traktować człowieka jak podmiot, widząc w nim już tylko jednostkę, egzemplarz gatunku, jednego z wielu, mo-

5 Zob. A. Renaut, Era jednostki. Przyczynek do historii podmiotowości, przeł. D. Leszczyński, Zakład Narodowy im. Ossolińskich Wydawnictwo, Wrocław-Warszawa-Kraków 2001.

6 Zob. F. Fukuyama, Koniec człowieka. Konsekwencje rewolucji biotechnologicznej, przeł. B. Pietrzyk, Wydawnictwo Znak, Kraków 2004.

7 Termin „podmiotywizm” przy całej swojej pretensjonalności wcale rzadko występuje w zwyczajnym obiegu filozoficznym. Posługują się nim np. Bogdan Baran czy Halina Perkowska. Por.: B. Baran, Postmodernizm, Wydawnictwo inter esse, Kraków 1992, s. 63; H. Perkowska, Postmodernizm a metafizyka, Wydawnictwo Naukowe Scholar, Warszawa 2003, s. 11-12. 
nadę, która nawet gdyby mogła mieć drzwi i okna, to jako jednostka wolałaby lub zostałaby zmuszona, by mieć je wszystkie szczelnie pozatrzaskiwane. Mono(seo)kracja to system rządów jednostki, ustanawiający w porządku aksjoetycznym (wykładniczych kulturowo wartości moralnych) przejście „od etyki autonomii do etyki niezależności”, od wolności rozumu do wolności kaprysu; od programowego działania do uporczywej spontaniczności; od jasnych, z góry danych celów do bezcelowego włóczęgostwa; od przewidywania do zgadywania; wreszcie od racjonalności, powszechności, obiektywności i niezmienności praw podmiotowych do zinstrumentalizowanego, zdelokalizowanego, zsubiektywizowanego, zmiennego niczym nastrój, kultu Ortegowskich „okoliczności" . Trawestując interesujące, trafne i celowo wyglądające na absurdalne spostrzeżenie Zygmunta Baumana, komentującego współczesne aplikacje Freudowskiej zasady przyjemności, według którego współczesny człowiek dąży do przyjemności „coraz większej i coraz bardziej przyjemnej"10, można orzec, że dąży on również do wolności coraz większej i coraz bardziej wolnej. Ani się zorientuje, jak ta rozciągnięta do granic wytrzymałości, zabsolutyzowana po Sartre'owsku wolność stanie się jego własną zatratą przechodząc w swoje dialektyczne przeciwieństwo - anonimowe zniewolenie; anonimowe, bo nie wiadomo dokładnie, skąd przychodzi, kto za nim stoi, do kogo należy odpowiedzialność za nie.

Monoseokracja wreszcie, na planie etycznym, oznacza przejście od skrajnego, bezwyjątkowego pryncypializmu etycznego do równie skrajnego, tyle że leżącego na radykalnie przeciwległym krańcu etycznego kontinuum sytuacjonizmu, z dopuszczania wyjątków od przewodniej reguły lub naczelnych zasad czyniącego równie jak tamte bezwzględną regułę postępowania wszystkich, którzy zdołali przepoczwarzyć się w jednostki. Tak oto paradoksalnie charakteryzujący Eliasowskie „społeczeństwo jednostek"11 brak przejrzystych, jednoznacznych i powszechnych reguł postępowania ustanawia nieznoszące sprzeciwu i nieuchylalne odtąd pryncypium nie-regularności - wiecznej spontaniczności, przypadkowości, nieprzewidywalności, zaskoczenia oraz improwizacji.

Im peraty w Sobości, pochwała bycia sobą za wszelką cenę, nawet za cenę siebie będącego nie-sobą, naśladującego wpływowego, im-

8 Zob. A. Renaut, Era jednostki, s. 66.

9 Zob. J. Ortega y Gasset, Medytacje o "Don Kichocie”, przeł. J. Wojcieszak, Warszawskie Wydawnictwo Literackie Muza, Warszawa 2008, s. 22.

10 Z. Bauman, Ponowoczesność jako źródło cierpień, Wydawnictwo Sic!, Warszawa 2000, s. 8.

11 Zob. N. Elias, Społeczeństwo jednostek, przeł. J. Stawiński, red. nauk. i przedm. do wyd. pol. M. Marody, Biblioteka Socjologiczna, Wydawnictwo Naukowe PWN, Warszawa 2008. 
perialnego innego, stając się autoimitacją która fałszując siebie, fałszuje innego przez przywłaszczenie sobie jego/jej tożsamości i eksponowanie jej, a czasem obnoszenie się z nią jak z własną; otóż, ów imperatyw Sobości, możliwy jest w ogóle do głoszenia - jak twierdzi Bernhard Waldenfels - dzięki jednemu z dwóch centralnych odkryć nowoczesności odkrycia autoreferencyjnego Siebie, które mówi o sobie "Ja"12, mnoży kolejne paradoksy, przedstawiane nam bądź jako nieznośna ciężkość bytu, bądź jako naturalna logika rozwoju ludzkości. Oto bowiem jednostka dąży do samopotwierdzenia i samourzeczywistnienia na drodze autonegacji i autodestrukcji, przez przyjęcie jako własny cudzego - bywa że bezimiennego - wzorca. Nie zauważa ona przy tym, że samopotwierdzając się i samourzeczywistniając w ten sposób, z jednej strony krzepnie - mówiąc po Levinasowsku - w materialności i egoiczności swojego istnienia, z drugiej strony zostaje $\mathrm{z}$ niego jakoby wydziedziczona. I nie może już nawet choćby pomyśleć o sobie tak, jak by sobie tego życzył Paul Ricoeur - o sobie samym jako innym ${ }^{13}$. Bycie sobą w rezultacie okazuje się niebyciem sobą albo lepiej byciem nie-sobą.

Myliłby się jednak ten, kto by sądził, że na zgliszczach negacji siebie ufundowana jest afirmacja innego. W tych sprawach nie może pozostać nic pewnego, nic ostatecznego ani nic wyglądającego na oczywiste. Zarówno Ja, jak i Inny to tylko jednostka - wydawałoby się niezastąpiona, a jednak wymienna. Bycie jednostką komplikuje zarówno egologię, jak i heterologię $e^{14}$. Odkąd podmiot ustąpił miejsca jednostce, jego określoność zastąpiona została nieprzezroczystością i rozproszeniem - jak o tym zaświadcza chociażby Paul Ricoeur - czyniąc zeń - mówiąc znów po Ricoeurowsku - „okaleczone”, ,rozszczepione” cogito ${ }^{15}$. W rzeczywistości jednostka nie jest ani soba, ani innym, lecz staje się ona tym, co José Ortega y Gasset obrazowo, acz brutalnie nazywa „widokiem”16. Mona Chollet mówi w tym kontekście o zjawisku ucieczki od siebie, które w jej przekonaniu stało się nie tylko plaga, ale i współczesnym przekleństwem $^{17}$.

12 Zob. B. Waldenfels, Podstawowe motywy fenomenologii obcego, s. 15.

13 Por. P. Ricoeur, O sobie samym jako innym, przeł. B. Chełstowski, Wydawnictwo Naukowe PWN, Warszawa 2005.

14 Por. np. M. Kruszelnicki, Drogi francuskiej heterologii, Wydawnictwo Naukowe Dolnośląskiej Szkoły Wyższej, Wrocław 2008.

15 Zob. P. Ricoeur, What Is a Text? Explanation and Understanding, w: A Ricoeurs Reader: Reflection and Imagination, red. M. J. Valdés, New York-London-Toronto-Sydney-Tokyo-Singapore 1991, s. 473.

16 Por. J. Ortega y Gasset, Człowiek i ludzie, przeł. H. Woźniakowski, w: idem, Bunt mas inne pisma socjologiczne, PWN, Warszawa 1982, rozdz. 2: Życie osobowe, s. 363-364.

17 Zob. M. Chollet, Tyrania rzeczywistości, przeł. A. Dwulit, Instytut Wydawniczy Książka i Prasa, Warszawa 2013, s. 109-112. 
Drugie znaczenie mono(seo)kracji, bez cząstki „-seo-" - monokracja - to rządy anonimowo dokonującej się uniformizacji, sprowadzania wszystkich do wspólnego mianownika, uzurpatorskiego odbierania jednostkom uzurpowanego przez nie same uprzednio, skoro tylko pogrzebały własną podmiotowość, prawa do samostanowienia. Monokracja oznacza dyktat jednego i powrót do monizmu, tyle że ów monizm wyraża się już nie w metafizycznej uogólniającej spekulacji, lecz w postmetafizycznym konkrecie praksis: jedno-myślności, mono-wzorców, mono-zachowań, mono-kultury. W odniesieniu do sfery publicznej przejawia się to $\mathrm{w}$ akcencie położonym na jej uniwersalizację, której - jak o tym piszą Marody i Giza-Poleszczuk - najwłaściwszym imieniem stała się globalizacja ${ }^{18}$.

W ten sposób w jednym słowie, mono(seo)kracja, udało się pomieścić antagonistyczne z natury tendencje, jakie trawią współczesną jednostkę. Korzystając z terminologii wypracowanej przez Davida Riesmana ${ }^{19}$, można je określić jako wewnątrzsterowność, która zachodzi, gdy mówimy o monoseokracji, oraz zewnątrzsterowność, gdy na myśli mamy samą tylko monokrację. Wszystkich terminów, mimo ich rozlicznych zapośredniczeń i konotacji, staram się używać głównie, jeśli nie wyłącznie w znaczeniu aksjoetycznym.

\section{Typologizacja negaksjologii}

Warto na moment zatrzymać się przy dokładniejszym objaśnieniu, co mamy lub możemy mieć na myśli, mówiąc o negaksjologiach. Pomijając skądinąd oczywistą pluralność tego sformułowania - tak bowiem jak nie istnieje jeden tylko system wartości pozytywnych, tak też próżno dociekać istnienia jednej tylko strategii negaksjologicznej - dobrze jest uświadomić sobie wieloznaczność, jaką pociąga za sobą ten termin.

Tym, co w pierwszym odruchu nasuwa się na myśl, gdy mowa o negaksjologii, jest skojarzenie jej z teorią przeciwwartości, z aksjologią negatywną. Dyskutowanie o aksjologii wartości negatywnych uprawnione jest już choćby z tego prostego powodu, o jakim wspomina przezornie we Wprowadzeniu do estymatyki Ortega y Gasset, że wartości są zawsze pozytywne lub negatywne, nigdy tylko pozytywne ani wyłącznie negatywne. Co prawda, jak mówi dalej Ortega, "dobro i zło nawzajem się wykluczaja, jedno jest przeciwieństwem drugiego, niemniej jednak i jedno, i drugie jest wartością: dobro - war-

18 Zob. M. Marody, A. Giza-Poleszczuk, Przemiany więzi społecznych, s. 298-299.

19 Zob. D. Riesman, Samotny tłum, przekł. oraz wstęp do wyd. pol. J. Strzelecki, Wydawnictwo Vis-à-vis/Etiuda, Kraków 2011. 
tością pozytywną; zło - wartością negatywną"20. Gdy mowa jest o aksjologii zwykle większość zainteresowanych odruchowo kojarzy ją z teorią wartości pozytywnych. Chciałbym zniuansować nieco ten obraz lub być może jedynie go upanoramicznić, upominając się o refleksję penetrującą przestrzenie i kryjówki również wartości negatywnych.

Pojęcie negaksjologii można traktować jako rewers aksjologi i wartości pozyty w n y ch, przy czym jedno do drugiego, mimo różnic, pozostaje w stosunku komplementarności.

Pojęcie negaksjologii może obejmować i oznaczać rehabilitację i dowartościowanie sfery tych wartości, których negatywność skojarzona jest z piętnem odmienności rozumianej w duchu Hansa Mayera, Colina Wilsona czy u nas np. Andrzeja Perzanowskiego. Z tego punktu widzenia na negaksjologię można się zapatrywać jako na aksjologię odmienności, outsiderstwa, różnego rodzaju nieprzystosowań, które generują w społeczeństwie en bloc szereg negatywnych asocjacji, skazujących jednostki z piętnem odmienności na stygmatyzację społeczna, marginalizację lub wykluczenie, wpędzające je prosto w objęcia samotności.

Pojęcie negaksjologii można, po czwarte, wykorzystywać również do opisywania zachowań polegających na negatywnej realizacji wa r tości pozytywny ch, dokonywanej czy to w sposób świadomy, czy poza kontrolą świadomości. Zaborcza miłość jest $\mathrm{w}$ takich razach pierwszym przykładem, który samorzutnie przychodzi na myśl. Innym może być solidarność wyłącznie z podobnymi sobie na podobieństwo sekty epikurejczyków czy Zrzeszenia Egoistów, proklamowanego przez Maxa Stirnera.

Kolejne znaczenie negaksjologii wiąże się z heurystyką przedstawiania wartości negatywnych w pozytywnym świetle, z równoczesnym przedstawianiem wartości pozytywnych jako negatywne. Przykładu tego typu zachowań dostarcza zdiagnozowany przez Fryderyka Nietzschego i doprecyzowany przez Maxa Schelera casus moralnego resentymentu.

Jeszcze inne pojęcie negaksjologii znajduje zastosowanie także przy opisie takich zjawisk moralnych, jak hipokryzja, pruderia, nieznoszący sprzeciwu pryncypializm, który dla ratowania normy - byle tylko dochować jej wierności - gotów jest poświęcić nawet przyjaźń czy miłość.

Wreszcie negaksjologia może się sprowadzać do aksjologi i nihi li z m u, dla którego centralną wartością jest nicość i poddawanie się jak twierdzi Alain Badiou - ślepej konieczności ${ }^{21}$. Marcia Sá Cavalcante

20 Zob. J. Ortega y Gasset, Wprowadzenie do estymatyki, w: idem, Dehumanizacja sztuki i inne eseje, przeł. P. Niklewicz, Czytelnik, Warszawa 1980, s. 148, 169.

${ }^{21}$ Zob. A. Badiou, Etyka, Przewodnik Krytyki Politycznej, przeł. P. Mościcki, t. 13, Wydawnictwo Krytyki Politycznej, Warszawa 2009, s. 47 i n. 
Schuback w swojej Pochwale nicości twierdzi wręcz, że cała aksjologia późnej nowoczesności tak naprawdę w gruncie rzeczy jest negaksjologią. Podstawą do tak radykalnej interpretacji aksjologii ponowoczesności jest, według Schuback, negatywne jej samookreślenie się jako „bycie tym, czego już nie ma"22.

Negatywnych wartości, wywoływanych lub/i utrwalanych w ramach procesów rekonfiguracji późnonowoczesnych systemów społeczno-moralnych, jest tak wiele, że omówienie ich wszystkich znacznie przekracza ramy nie tylko tego artykułu. Toteż poprzestańmy może jedynie na ich hasłowym wyliczeniu z dodaniem krótkiego komentarza. Część z nich, jeśli nie wszystkie, chętnie kwalifikowałbym - posługując się określeniem wypracowanym wspólnie z Marcinem T. Zdrenką - jako "schorzenia układu moralnego", trawiące ponowoczesne społeczeństwa. Wśród nich należy koniecznie wymienić:

1. Komercjalizatorstwo: za wartościowe można uznać wyłącznie to, co pozwala się skomercjalizować, tzn. urynkowić, zarekomendować jako wartościowe oraz sprzedać z zyskiem. Działaniom tego rodzaju podlegają nie tylko, co oczywiste, wytwory kultury materialnej, ale i duchowej, a nawet wysokiej.

2. Ko n su m e r y z m: wartość przysługuje jedynie temu, co można uczynić przedmiotem konsumpcji, niezwiązanej bezpośrednio z zaspokajaniem bieżących potrzeb życiowych, lecz służącej mówiąc językiem znanym z Arystotelesowskiej Metafizyki wygodom życia. Wartości konsumpcyjne, mimo że niższe od moralnych, uchodząc za bardziej od tamtych podstawowe, wywołują presję na preferencję skierowaną głównie, jeśli nie wyłącznie, w ich stronę. Wartości niekonsumpcyjne, jak np. moralne, muszą $\mathrm{w}$ tej sytuacji - jeśli mają się $\mathrm{w}$ tak skonstruowanym systemie aksjonormatywnym ostać - ulec tej samej presji. Zjawisko to, w języku aksjologicznym, można opisać jako r e d u k cję a k s jo lo g i c z n ą. Polega ona generalnie na sprowadzaniu wartości wysokich do niskich, wraz z ich trywializacją względnie na zastępowaniu wartości wysokich niskimi.

3. Ekonomyślenie: jest to termin zapożyczony od Alvina Tofflera ${ }^{23}$. Oznacza on „obsesję ekonomiczną" ${ }^{24}$ wyrażającą się w ekonomizacji, tj. podporządkowywaniu standardom, kryteriom i wartościom ekonomicznym wszystkiego, co tylko możliwe - nawet tego, co z ekonomią nie ma żadnego związku. Mam

22 M. Sá Cavalcante Schuback, Pochwała nicości. Eseje o hermeneutyce filozoficznej, z j. szwedzkiego przeł. L. Neuger, Wydawnictwo UJ, Kraków 2008, s. 41.

${ }_{23}$ Zob. np. A. Toffler, Ekospazm, przeł. E. Szymańska, Czytelnik, Warszawa 1977, s. 122.

24 Ibidem. 
tu na myśli szczególnie sferę moralna, ale też prawna, artystyczną i religijną.

4. Merkantylizm: termin ten pochodzi od Ericha Fromma ${ }^{25}$. Częściowo wiąże się on z poprzednimi, a zwłaszcza z ekonomyśleniem. Przy jego pomocy opisuje się zjawisko, które również za Frommem można określić jako utowarowienie. Wynika z niego, że wartość przysługuje jedynie temu, co daje się utowarowić, a jako takie zareklamować i sprzedać z zyskiem. Merkantylizacji poddaje się nie tylko dobra materialne i usługi, ale też samego człowieka, czyniąc kłopotliwym, jeśli nie bezużytecznym, pojęcie godności ludzkiej. Wartość człowieka wycenia się niczym wartość dowolnego towaru, traktując ją jako wartość wymienną ${ }^{26}$. Człowiek jako taki, w myśl tej doktryny, (jeszcze) nie jest nic wart. Dopiero rozwinięte zdolności, sprawności, umiejętności, nabyte doświadczenie, pozyskana wiedza, zajmowane miejsce na drabinie społecznej, posiadane kontakty, znajomości i wpływy, status materialny - wszystkie lub co najmniej część z wymienionych własności, w zależności od zakresu, w jakim występuje, decyduje o wartości poszczególnych osób.

5. Fin an sizm: jest to zjawisko pokrewne poprzednim, zamiennie określane czasem jako „zdegenerowany kapitalizm”, antycypowane przez Arystotelesa terminem "chrematystyka" 27 , posiadającym swoje odpowiedniki także w słowach "bankokracja”, "giełdyzacja” czy "kapitalizm finansowy”. Finansizm kładzie nacisk na finansyzację $e^{28}$, czyli - mówiąc prosto - upieniądzowie-

25 Por. E. Fromm, Niech się stanie człowiek. Z psychologii etyki, przeł. R. Saciuk, Wydawnictwo Naukowe PWN, Warszawa-Wrocław 1999, s. 61-73.

26 Ibidem, s. 62.

27 Cyt. za: M. Ratajczak, Ekonomia i edukacja ekonomiczna w dobie finansyzacji gospodarki, s. 3, http://www.pte.pl/kongres/referaty/Ratajczak\%20M/Ratajczak\%20M.\%20-\%20Ekonomia\%20i\%20edukacja\%20ekonomiczna\%20w\%20dobie\%20finansyzacji\%20gospodarki.pdf (dostęp: 02.05.2014). Zob. też: idem, Finansyzacja gospodarki, „Ekonomista” 2012, nr 3, s. 281-302.

28 Obok terminu "finansyzacja” upowszechnia się także, wybijając się w najnowszych opracowaniach naukowych i dyskursie publicystycznym na pozycje lidera, termin "finansjalizacja”. Por. P. H. Dembiński, Finanse po zawale. Od euforii finansowej do gospodarczego ładu, przeł. Ł. Komuda, Wydawnictwo Studio Emka, Warszawa 2011. Profesor ekonomii, Paul H. Dembinski z Uniwersytetu we Fryburgu, współtwórca i szef Observatoire de la Finance (Obserwatorium Finansów) w Genewie, odnosi się do tego zagadnienia także w rozmowie z Jackiem Żakowskim, przeprowadzonej dla tygodnika „Polityka”. Zob. Zagubiona rzeczywistość - rozmowa J. Żakowskiego, „Polityka" 2012, nr 5, s. 21-23; wersja elektroniczna: http://www.polityka.pl/tygodnikpolityka/swiat/1523889,1,wywiad-zakowski-i-dembinski-o-recepcie-na-kryzys-cz-i.read oraz http://www.polityka.pl/tygodnikpolityka/swiat/1523933,1, wywiad-zakowskii-dembinski-o-recepcie-na-kryzys-cz-ii.read (dostęp: 04.03.2014.). Na ten temat zob. także np.: M. Księżyk, Źródła i ekonomiczne skutki kryzysów finansowych, „Nierówności 
nie kontaktów, transakcji i czerpanych z nich zysków. Profesor Marek Ratajczak z Uniwersytetu Ekonomicznego w Poznaniu zwraca uwagę, że:

Definicje finansyzacji akcentują na ogół szczególną i rosnącą rolę sfery finansowej oraz kryteriów finansowych $\mathrm{w}$ funkcjonowaniu życia ekonomicznego i społecznego. W wąskim znaczeniu finansyzacja kojarzona jest przede wszystkim z rosnącym znaczeniem działalności finansowej w aktywności podmiotów ekonomicznych o charakterze niefinansowym. Konsekwencją tego jest zmiana strumieni dochodów, w których coraz większy udział mają dochody czerpane właśnie z działalności finansowej, a nie z tradycyjnie rozumianej działalności operacyjnej i inwestycyjnej ${ }^{29}$.

Finansyzacja proklamuje jako powszechnie obowiązującą nadrzędną i dominującą wartość pieniądza, w stosunku do której wszelkie inne wartości nabierają charakteru pochodnego i wtórnego. Peter Sloterdijk mówi w tym kontekście o „Najbardziej efektywnej totalizacji, objęciu całej Ziemi przez pieniądz

Społeczne a Wzrost Gospodarczy" 2013, nr 30, s. 5-24; K. Messyasz, Między wspólnota położenia a jednościa pokoleniowa, „Władza Sądzenia” 2014, nr 3: Radykalny inkluzywizm. Orygenes zamiast Schmitta, red. K. Kubala, K. Nawratek, s. 79-97. Terminem „finansjalizacja" oraz zagadnieniem, które jest nim oznaczane, posługuje się także socjolog z Uniwersytetu Jagiellońskiego, profesor Wiesław Gumuła. Do konstytutywnych elementów finansjalizacji zalicza on: w aspekcie ekonomicznym: „hipertrofię rynków finansowych", "ubankowienie społeczeństwa”, "transformację światowego systemu gospodarczego [...] w system oparty na rynkach finansowych"; w wymiarze socjologicznym zaś: zapośredniczenie więzi społecznych pieniądzem bezgotówkowym, zastępowanie interakcji oddziaływaniami jednostronnymi, zakłócenie wzajemnego odnoszenia się ludzi do siebie przez niestabilność i nieprzewidywalność pieniądza, „zastępowanie kontaktów bezpośrednich kontaktami zapośredniczonymi przez różnego rodzaju media”, „delegowanie przez masy społeczne władzy ekonomicznej, w którą brzemienny jest pieniądz, na rzecz instytucji finansowych oraz osób decydujących o jego przeznaczeniu”, przeobrażanie się „relatywnie stabilnych i przewidywalnych więzi społecznych w stosunki o płynnym, nietrwałym i zaskakującym charakterze”, wreszcie wytwarzanie „nowej polaryzacji społecznej”, w której „Z jednej strony bogacą się elity finansowe, a z drugiej - powiększa się liczba ludzi wykluczonych z głównego nurtu życia gospodarczego". Co ważne, szczególnie w kontekście negaksjologicznym, zdaniem Gumuły, „Finansjalizacji towarzyszy narastająca fala tchórzostwa moralnego, rozlewającego się na wszystkie domeny życia. [...] Dominacja instytucji finansowych nad przedsiębiorstwami produkcyjnymi i usługowymi prowadzi coraz częściej do destrukcji elementarnych więzi moralnych oraz upowszechnienia cynizmu, cwaniactwa, braku wzajemności i lojalności wobec pracowników"; rodzi „gotowość do różnych kompromisów moralnych oraz zachowań, których nie akceptowalibyśmy w innych okolicznościach". Zob. W. Gumuła, Zjawisko finansjalizacji, ,Znak” czerwiec 2015, nr 721, s. 13-19; przywołane cytaty pochodzą ze s. 13-16.

29 M. Ratajczak, Ekonomia i edukacja ekonomiczna w dobie finansyzacji gospodarki, s. 2. 
we wszystkich jego odmianach (jako towaru, jako tekstu, jako liczby, jako obrazu i jako prominencji)" ${ }^{\prime \prime 2}$. W rezultacie wartość wolno przypisać bądź wyłącznie samym zasobom finansowym, bądź jedynie temu, co daje się wymienić lub w inny sposób ulega dyktatowi pieniądza. Przeczuwając związane z tym trudności, szczególnie natury aksjomoralnej, Marek Ratajczak przytomnie stwierdza, że „W efekcie dopiero teraz, gdy pieniądz z roli dobrego sługi sfery realnej stał się w znacznej mierze jej nie zawsze dobrym panem, zadajemy sobie wiele pytań, na które nie ma prostych i wyczerpujących odpowiedzi" ${ }^{\prime 31}$.

6. Hedonitrofizm: to konglomerat wcale nowych poglądów, zgodnie z którymi wartościowe jest wyłącznie to, co (wprost) budzi lub (w efekcie) prowadzi do przyjemności. Jednocześnie przyjemność urasta nie tylko do rangi wartości centralnej, ale też staje się kryterium i miernikiem wszelkich wartości. Dążeniom tym patronuje $\mathrm{z}$ wysoka spostmodernizowana zasada przyjemności, którą Zygmunt Bauman ujął w zgrabnej i zmyślnej formule "dążenia do przyjemności [...] coraz większej i coraz bardziej przyjemnej" ${ }^{32}$. Peter Sloterdijk, śledząc wzajemne powiązania między hedonitrofizmem i konsumeryzmem (choć sam określa je przy pomocy tradycyjnych terminów: hedonizm i konsumpcjonizm), ten pierwszy, nieco alegorycznie, definiuje w kategoriach ,gigantycznej cieplarni odprężenia" ${ }^{33}$.

7. Rywalizacjonizm (resp. konkurentyzm): podejście, które podstawowej wartości ludzi, idei, spraw i zdarzeń upatruje w ich konkurencyjności. Jeśli ktoś lub coś nie jest konkurencyjne, nie posiada lub należy temu odmówić wartości, uznając za bezwartościowe. Kryje się za tym przekonanie mówiące o tym, że wartość przysługuje jedynie temu, co nie tylko zdolne jest rywalizować, ale co z rywalizacji wychodzi zwycięsko. Przy okazji warto zwrócić uwagę na interesującą zmianę aksjosemantyczną, jakiej uległ termin „,konkurencja”. Otóż, zgodnie z łacińską etymologią słowa, con-curro, obok najbardziej rozpowszechnionej konotacji 'uderzyć na siebie', 'potykać się', znaczy także 'zbiegać się razem', 'zetknąć sięe, 'równocześnie dziać się, 'schodzić się'. Gdy przedrostek con- wskazuje na wspólnotę działania, to czasownik curro sugeruje 'bieg', 'pośpiech', 'pęd'. Konkurencja

30 Zob. P. Sloterdijk, Kryształowy pałac. O filozoficzna teorię globalizacji, przeł. B. Cymbrowski, Wydawnictwo Krytyki Politycznej, Warszawa 2011, rozdz. 1, s. 11.

31 M. Ratajczak, Ekonomia i edukacja ekonomiczna w dobie finansyzacji gospodarki, s. 13.

32 Z. Bauman, Ponowoczesność jako źródło cierpień, s. 8.

33 Por. P. Sloterdijk, Kryształowy pałac, s. 213. 
zatem to inaczej współdążność, bez elementu antagonizującego. Gdyby jeszcze do tego zaryzykować to, co z Marcinem T. Zdrenką nazywamy "fałszywą etymologią", która mimo swojego niezakładanego jako cel fałszu - wynikającego ze stosowania nie zawsze uprawnionych, $\mathrm{z}$ etymologicznego punktu widzenia, zabiegów wywodzenia genezy słów i związanych z nimi znaczeń - wielokrotnie prowadzi do zaskakujących, niespotykanych i inspirujących odkryć, wówczas okazałoby się, że słowo „konkurencja” (od con- - 'wspólnie', 'razem' oraz curo - 'dbać o coś', 'troszczyć się', 'zarządzać') zamiast nastawienia na rywalizację, współzawodnictwo, może oznaczać także wspólną troskę, współdziałanie, wspieranie się dla osiągnięcia wspólnego celu. Rozróżnienie znaczeń słów „rywalizacja” i „konkurencja" podług tego klucza pozwoliłoby tym pierwszym opatrywać działania oparte na współzawodnictwie, obliczonym na indywidualne lub grupowe eliminowanie przeciwnika, tym drugim zaś można by określać działania oparte na indywidualnej lub/i ponadindywidualnej kooperacji stron i podmiotów.

8. Kreatywizm: nieco żartobliwie mówiąc, jest to współczesna, świecka, zhumanizowana wersja spopularyzowanego w średniowiecznej teologii kreacjonizmu. Utrzymuje się tu, że niepowątpiewalną wartość posiadają jedynie wytwory ludzkiej pomysłowości, zdolnej generować coraz to nowe, śmiałe, oryginalne, wyjątkowe, niespotykane, rewolucyjne, kontrowersyjne, zaskakujące, nietuzinkowe etc. idee, skojarzenia, koncepcje, teorie, modele, plany, strategie, produkty itp. Każda myśl, twór, posunięcie, działanie itd. nieopieczętowane stemplem wynalazczości stają się zrazu wtórne, wsteczne i bezużyteczne, a jako takie eo ipso bezwartościowe lub, w najlepszym razie, przeciwwartościowe.

9. In now a cjo ni z m: jak łatwo zgadnąć, jest to strategia negaksjologiczna, pokrewna kreatywizmowi. Zasadniczo kładzie się w niej akcent na wartościowość tylko tych zamierzeń i działań, które zakładają lub/i wprowadzają (najlepiej) wprost lub pośrednio, do określonego systemu (społecznego, ekonomicznego, gospodarczego, politycznego, naukowego) nową wartość lub jakość. Zasada działania jest tu wyjątkowo zbieżna z tą, która charakteryzuje hedonitrofizm. Głosi ona mianowicie - parafrazując Baumana - że należy dążyć do nowości coraz to większej i coraz nowszej i to koniecznie we wszystkich dziedzinach życia społecznego. Innowacjonizm manifestuje przekonanie, że „to, co nowe, jest z definicji dobre" 34 , a więc ",to, co nowoczesne, jest tym

34 Zob. L. Kołakowski, Cywilizacja na ławie oskarżonych, w: O kryzysie, Rozmowy w Castel Gandolfo 1985, t. 2, przygot. i przedm. opatrzył K. Michalski, przeł. A. Klu- 
samym lepsze" ${ }^{\prime 35}$. Pomijając już kwestię lub raczej wątpliwość, czy się $\mathrm{w}$ tym podejściu przypadkiem nie zechciał odrodzić nieco unowocześniony romantyczny mit wiecznego postępu ludzkości, zmierzającej jakoby, po Heglowsku, ku własnemu absolutowi; odkładając na bok także liczne a istotne zastrzeżenia, jakie $\mathrm{w}$ związku z tym wysuwał $\mathrm{w}$ wielu miejscach i przy różnych okazjach (chociażby) Leszek Kołakowski ${ }^{36}$, trudno nie wzbudzić krytycznej refleksji dotyczącej co najmniej dwóch spraw: po pierwsze, wiary $\mathrm{w}$ ustawiczny postęp $-\mathrm{z}$ towarzyszącym temu pytaniem, czy i jak możliwy jest nieskończony, niewyczerpany, bezkresny postęp, który staje się w efekcie postępem postępu; po drugie, czym tak naprawdę innowacjonizm grozi w dziedzinie moralnej, przy założeniu, że jesteśmy w ogóle w stanie przewidzieć choćby część jego skutków na tym polu. Poza tym ciśnie się na usta jeszcze jedna ważna kwestia, a właściwie problem i to problem, jak się wydaje, natury podstawowej: czy - a jeśli tak, to w jakim zakresie i na jakich zasadach, etyka dopuszcza innowacje moralne oraz czym ewentualnie miałyby one być lub nie być.

10. E fekty w i z m: jest to zespół przekonań i działań, zwykle zinstytucjonalizowanych, zorganizowanych wokół i samozwrotnie konfirmujących, mówiąc najogólniej, przymus wydajności we wszystkich strategicznych dziedzinach życia społecznego. Ogólnie rzecz biorąc, chodzi o to, by za wartościowe uznawać takie idee, posunięcia, plany i działania, które w najwyższym stopniu waloryzują takie cechy, jak: produktywność, nastawienie na osiąganie coraz to lepszych wyników, sprawność działania i skuteczność. Zachowania, idee i przedsięwzięcia uznane $\mathrm{z}$ tego punktu widzenia za nieefektywne (bezproduktywne, bezwynikowe, niesprawne oraz nieskuteczne) automatycznie należy uważać za bezwartościowe. Pytanie, czy akty moralne mogą być efektywne, a jeśli nie, to czy właśnie dlatego należy poniechać w życiu społecznym moralnej jego organizacji. Znamienne i dane jakoby ku przestrodze, że jeśli w łacińskim mateczniku słowa "efektywność" (effectus, effectio) pominąć, przypadkiem lub celowo, jedną tylko literę " $\mathrm{C}$ ", otrzymując słowo effetus, wówczas jego znaczenie zmienia się radykalnie do postaci: 'wyczerpany', 'osłabiony', 'bezsilny'.

11. Ekspansy wizm: to kolejny ze standardów późnonowoczesnych strategii negaksjologicznych, zbliżony do efektywizmu.

ba, Instytut Nauk o Człowieku, Res Publica, Warszawa 1990 , s. 75.

35 Ibidem, s. 76.

36 Por. np. ibidem. 
Napędza je myślenie w kategoriach „dalej, mocniej, prędzej, więcej". Idzie o to, by jak najbardziej rozszerzyć, rozpostrzeć, roztoczyć, rozprzestrzenić - narzucając choćby i siłą - swoje wpływy społeczne, polityczne, gospodarcze, światopoglądowe i inne. Ekspansywizm hołduje, na ogół, zachłanności i nieumiarkowaniu brzemiennym przekonaniem, że propagowane wzorce należy $\mathrm{w}$ ten sposób rozprzestrzeniać jako najlepsze $\mathrm{z}$ możliwych. W odniesieniu do sfery aksjomoralnej powstaje natychmiast pytanie, czy, jakie, w jakim zakresie, a także w oparciu o jakie przesłanki lokalnie wypracowane kryteria moralnej oceny i postępowania zasługują na upowszechnienie. Denis de Rougemont ekspansywistyczne skłonności i tendencje opatruje mianem "gigantyzmu" ${ }^{37}$, którego zasadniczymi elementami są „babelizacja”"38 i „kult masowości” ${ }^{39}$.

12. Indywiduomania: podejście to ponad wszystko przedkłada wartość izolującej się ze społecznych obciążeń, ograniczeń i konwenansów, samodzielnej i niezależnej, nieszablonowej, wyznaczającej nowe standardy jednostki. Stygmatyzuje się tutaj wszelkie przejawy liczenia się ze zbiorowością jako obniżające indywidualne potencjały wzrostu, a w rezultacie zagrażające im. Indywiduomania silnie łączy się z wcześniej wymienionymi zasadami ponowoczesnej negaksjologii.

13. Ranking ofilia: inaczej panklasyfikacjonizm; tęgie rozmiłowanie w hierarchizującym porządkowaniu wartości wszelakich domen publicznych oraz indywidualnych sprawności i aktywności. Rozumowanie to naznaczone jest przeświadczeniem, że rankingowanie wartości ma charakter obiektywny i nie znosi sprzeciwu, a ponadto, że to, co nie zostało oficjalnie sklasyfikowane lub zostało sklasyfikowane negatywnie bądź na niższej pozycji, należy uznać za bezwartościowe, ujemnie wartościowe (przeciwwartościowe) lub mało wartościowe $\mathrm{w}$ stosunku do tego, co w ogóle zostało włączone do klasyfikacji albo sklasyfikowane zostało pozytywnie bądź jako wartość wyższa.

14. Certyfikoholia: szeroko rozpowszechniona praktyka dopuszczania do użytku lub praktyki instrumentów i działań, które zyskały wymagane atesty, potwierdzenia, pozwolenia bądź upoważnienia. Każdy wyrób, usługa, aktywność, przekonanie, instytucja, osoba, które nie zdołały uzyskać stosownego certyfikatu (nie zostały pozytywnie zweryfikowane), niezależnie od

37 Zob. D. de Rougemont, Udział Diabła, przeł. A. Frybes, Wydawnictwo Wodnika, Warszawa 1992, s. 186-187, 189.

38 Ibidem, s. 137.

39 Ibidem, s. 130. 
tego, czy - zwłaszcza w sferze praktyk moralnych - możliwe jest w ogóle takie certyfikowanie, uchodzą za obiektywnie bezwartościowe i przeciwpowinne.

15. Profes jo naliz m: nieodmiennie łączy się z dwiema poprzednimi taktykami. Za wartościowe uważa się tutaj każde sprofesjonalizowane działanie i pogląd. Profesjonalizacja oznacza uporczywe dążenie do ustawicznego podnoszenia posiadanych kompetencji, zdobywania kwalifikacji, rozwijania fachowości, wybijania się na eksperckość. Wartościowe jest jedynie to, co profesjonalne, to zaś, co trąci amatorstwem, mimo iż wykonywane jest $\mathrm{z}$ godnym podziwu znawstwem, zasługuje na lekceważące miano bezwartościowego dyletanctwa. Pytanie znów, co to oznacza szczególnie dla etyki. Czy np. winna się ona wyzbyć całkowicie aspiracji pozakodeksowych jako nieprofesjonalnych i prowizorycznych?

16. Panaktywizm: forsuje zasadę aktywizmu (społecznego, zawodowego, naukowego, sportowego etc.) przeciwko zasadzie refleksyjności. Jedynie wszelkiego rodzaju (najlepiej sprofesjonalizowana i zautomatyzowana) aktywność może być sklasyfikowana jako wartość pozytywna. Każda myśl, działanie, przedsięwzięcie, które staje na przeszkodzie szeroko pojętej aktywności z konieczności uznane być musi za nieprzedstawiające sobą większej lub żadnej wartości, a jako takie winno być zaniechane. Każdy więc, dajmy na to, kto zamiast po prostu i od razu (niejako odruchowo) działać, zastanawia się nad tym, jak to zrobić, jak się do tego przygotować, jakie mogą być tego konsekwencje, jawi się zrazu jako typ cokolwiek podejrzany, a ponadto pasożytniczy, próżniaczy i ogólnie szkodliwy. Takich należy przywoływać do porządku, bo z samego myślenia - jak się tu przyjmuje uważać - jeszcze nic nie wynika. Wyniki daje dopiero działanie. Bez odpowiedzi pozostawmy pytanie, czym tego rodzaju nastawienie, w połączeniu z automatyzmem i bezrefleksyjnościa, może skutkować na gruncie działań moralnych.

17. Hiperleksja (nie mylić z rzadkim zaburzeniem, będącym odwrotnością dysleksji): inaczej „inflacja prawa” („inflacja legislacyjna”), „nadregulacja”, „biegunka prawna”. Zjawisko to polega zasadniczo na fasadowo kontrolowanej lub wymykającej się spod kontroli nadprodukcji przepisów prawa, nieprzystającej do rzeczywistych potrzeb i wyzwań życia społecznego. Przy czym nie chodzi tu o sam proces nadmiernego tworzenia prawa, ile o towarzyszący temu pogląd, że należałoby skodyfikować każdą dziedzinę życia społecznego i indywidualnego, poddając je wyłącznie prawnej regulacji, kontroli, sankcjom i egzekucji. Pozostawiam otwarta, do dalszych dyskusji i rozstrzygnięć, 
kwestię redukcji całej aksjosfery do dziedziny prawnej oraz jej konsekwencji (przede wszystkim moralnych, społecznych i edukacyjnych).

18. Amoralny familizm: termin utworzony i wprowadzony pierwotnie do politologii przez Edwarda C. Banfielda, amerykańskiego uczonego, na oznaczenie zachowań, w których na czoło wysuwa się preferencja aksjologiczna, ukierunkowana na potrzeby członków własnej rodziny (stąd familizm). Dziś termin ten stosuje się w szerszym planie, choć właściwie przeszedł już całkowicie na pozycje psychologiczne. W kontekście aksjologii rozpatrujemy go jako pogląd, który, po pierwsze, premiuje i utrwala w świadomości i działaniach społecznych dychotomię "swój-obcy", a po wtóre, nagradza jako wartościowe jedynie te z nich, które zachowują programową stronniczość wobec "swoich", z równoczesną obojętnościa, wrogością bądź nienawiścią wobec rzeczywistych lub urojonych „obcych".

19. Wizerunkostwo: inaczej etykietyzm lub prezentyzm. Pogląd, który osoby, działania i myśli podporządkowuje, co do ich wartości, pozakasjologicznym strategiom wizerunkowo-marketingowym. W rezultacie wartościowe okazuje się wyłącznie to, co posiada chwytliwy, zmyślnie opakowany i dobrze się kojarzący wizerunek lub etykietę. Poddawanie kogoś lub czegoś ocenie oznacza, w istocie, etykietowanie ze względu na przysługujący temu komuś lub czemuś wizerunek. W konsekwencji, nie liczy się to, jakie rzeczywiście (tzn. ukryte za maską wizerunku bądź szyldem etykiety) wyznaje się i realizuje wartości, tylko to, jak się skutecznie potrafi zaprezentować i wypromować. Skutki tego podejścia dla sfery moralnej są z góry wiadome.

\section{Anomia - apatia - atomia}

Pojęcie negaksjologii znajduje szczególne zastosowanie przy określaniu profilu aksjologicznego późnej nowoczesności. Stąd można mówić o negaksjologiach ponowoczesności (terminy "późna nowoczesność" i "ponowoczesnośćc traktuję jako równorzędne). Ich newralgiczne momenty, poza omówionymi, stanowią wymienione w tytule mojego przedłożenia anomia, apatia i atomia. To filarowe wartości współczesnych negaksjologii. Wszystkie trzy kulminują ostatecznie w samotności wraz z jej derywatami, takimi jak osamotnienie, wyobcowanie i depersonalizacja. Dlatego uzasadnione wydaje się mówić w tym kontekście o mono(seo)kracji.

A n o m i a, jak podpowiada grecki źródłosłów, a-nomos oznacza sensu stricto 'bez-prawie', obywanie się bez prawa, neutralność wobec nie- 
go. Sensu largo można z kolei mówić o samowładnym uchylaniu przez jednostki wszelkich, nie tylko prawnych, ale też grzecznościowych, towarzyskich, konwencjonalnych, religijnych lub/i moralnych uregulowań sfery publicznej i prywatnej, prowadzącym w rezultacie do deregulacji (scil. rozproszenia lub wręcz zaniku) więzi społecznej, pozwalającej jednostkom łączyć się w organizmy ponadindywidualne. Anomia społeczna cechuje się „załamaniem reguł”. Oznacza ten „okres w historii ludzkości", w którym wszystko może się zdarzyćc ${ }^{40}$.

W książce Life Chances Ralph Dahrendorf utrzymuje, że postępujące procesy anomizacyjne $\mathrm{w}$ późnonowoczesnych społeczeństwach przeciwstawiają sobie czynniki, które $\mathrm{w}$ normalnych warunkach powinny ze sobą współgrać i kooperować. Są nimi "opcje” (options) i „więzy” (ligatures). „Podczas gdy więzy umocowują pozycje społeczne i ludzi, którzy je piastują w przestrzeni społecznej, opcje tworzą - w zasadzie nieograniczony - arsenał odmian w zachowaniu. Więzy są dane, opcje są poszukiwane" ${ }^{\prime 41}$. We współczesnych społeczeństwach, jak argumentuje dalej autor:

redukcja, a w ostatecznym efekcie, destrukcja więzów do pewnego punktu towarzyszyła, a być może nawet była odpowiedzialna za zwiększenie wyborów; lecz począwszy od tego punktu, wybory zaczynają tracić swe znaczenie, ponieważ dokonują się w społecznej próżni, czy może lepiej, społecznej pustyni, na której żadne koordynaty nie czynią pewnych kierunków [wyboru] bardziej pożądanymi od innych ${ }^{42}$.

Wzrost znaczenia mechanizmu wyboru między niepomiernie rosnącymi i traktowanymi jako $\mathrm{w}$ zasadzie równorzędne opcjami dokonuje się kosztem rozpadu więzi społecznych, czego widomym objawem staje się, zdaniem Dahrendorfa, wzmagająca na sile presja na znoszenie wszelkich różnic we wszelkich możliwych do pomyślenia kontekstach życia społecznego i publicznego.

Dla niektórych - czytamy w Life Chances - bycie chrześcijaninem zaczyna oznaczać nieposiadanie żadnej wyróżniającej się wiary; wyzwolenie kobiet zaczyna oznaczać, że nie powinno być żadnych społecznych różnic między mężczyznami i kobietami; grey panthers żądają zniesienia starości, podczas gdy wyzwoliciele dzieci domagają się zniesienia dzieciństwa. [...] Zniszczenie więzów w znaczących odłamach niektórych społeczeństw zaczęło prowadzić do redukcji złożoności, co z kolei pociagga za sobą zmniejszenie szans życiowych: znikają same możliwości dokony-

40 M. Marody, A. Giza-Poleszczuk, Przemiany więzi społecznych, s. 19.

41 R. Dahrendorf, Life Chances. Approaches to social and political theory, University of Chicago Press, Chicago 1979, s. 75.

42 Ibidem, s. 31-32. 
wania wyborów, które nowoczesne społeczeństwo zamierzało oferować wszystkim ${ }^{43}$.

Gdy Robert K. Merton źródeł anomii doszukuje się w „niedopasowaniu między uznawanymi przez społeczeństwo wartościami a dostępnymi jednostkom wzorami zachowan'" ${ }^{44}$, to Ralph Dahrendorf upatruje ich $\mathrm{w}$ rozpadzie społecznych więzi, prowadzących $\mathrm{w}$ następstwie do "załamywania się dotychczas obowiązujących reguł życia społecznego", "nadających kierunek i spoistość działaniom jednostek"45. Poza wszystkim anomia społeczna wydaje się naturalną konsekwencją społecznych i kulturowych procesów depodmiotywizacji, które Ulrich Beck woli określać bardziej swojsko brzmiącym terminem „indywidualizacja” 46 .

A patia, znów odwołując się do greckiego korzenia tego słowa, w sensie ścisłym uprzytamnia nam, że chodzi o bezuczuciowość, bezafektywność, (emocjonalne) nieporuszenie. W ogólniejszym, moralnym sensie apatia oznacza stan moralnej niewrażliwości, obojętności lub lekceważenia cudzych praw, pragnień lub/i potrzeb - jakiekolwiek by one były. Apatia przeniesiona na plan społeczny i traktowana jako indywidualna i grupowa strategia negaksjologiczna, prowadząca do monoseokracji - rządów samotności - względnie utrwalająca ją, nie tylko jest ubocznym skutkiem procesów anomizacyjnych, ale też prowadzi do aksjologicznego odrętwienia lub wręcz trwonienia aksjomoralnego kapitału jednostek i społeczeństw, skutkując in effectu takimi zjawiskami jak: znieczulica moralna, spadek potencjału zaufania społecznego, a także wzrost wzajemnej agresji i wrogości.

Apatia, powiedzmy na koniec, pociąga za sobą jako swój ostatni rezultat, a to $\mathrm{m}$ i ę, czyli radykalny rozpad zwartej struktury społecznej na społeczne atomy - jednostki, których differentia specifica stają się odtąd: egotyzm, narcyzm, wyrachowanie, instrumentalizacja kontaktu społecznego i ucieczka od innych.

Jakkolwiek by patrzeć na rekonstruowany tu model ponowoczesnej jednostki, jedno nie ulega kwestii: w każdym z rozpatrywanych przypadków ostatnie słowo nieodmiennie należy do dławiącej ją samotności, niezależnie od tego, jaką in concreto ta samotność przyjmuje postać.

43 Ibidem, s. 36.

44 M. Marody, A. Giza-Poleszczuk, Przemiany więzi społecznych, s. 20-21.

45 Ibidem, s. 21.

46 Por. U. Beck, E. Beck-Gernsheim, Individualization and "precarious freedom". Perspectives and controversies of a subject-oriented sociology, w: Detraditionalization. Critical Reflections on Authority and Identity, red. P. Heelas, S. Lash, P. Morris, Blackwell Publishers, Oxford 1996. Zob. też: M. Marody, A. Giza-Poleszczuk, Przemiany więzi społecznych, s. 21-24. 


\section{Streszczenie}

\section{Negaksjologie sfery publicznej. Społeczna anomia, apatia i atomia, czyli w kręgu mono(seo)kracji}

\section{Słowa kluczowe}

Negaksjologia; sfera publiczna; anomia; apatia; atomia; samotność; monoseokracja; egotyzm; narcyzm; indywidualizm; moralność indywidualna i publiczna; ponowoczesność

W artykule tym podejmuję zagadnienie negaksjologicznych strategii ponowoczesności. Terminem tym oznaczam negatywne aksjologie bądź aksjologie negatywnych wartości. Wśród nich można wyróżnić wiele metod, ujęć i tendencji. Część z nich jest bardziej szczegółowa, część z kolei posiada bardziej ogólny charakter. Do szczegółowych strategii negaksjologicznych zaliczam: komercjalizatorstwo, konsumeryzm, ekonomyślenie, merkantylizm, finansizm, hedonitrofizm, rywalizacjonizm, kreatywizm, innowacjonizm, efektywizm, ekspansywizm, indywiduomania, rankingofilia, certyfikoholia, profesjonalizm, panaktywizm, hiperleksja, amoralny familizm, wizerunkostwo. Spośród ogólniejszej natury orientacji negaksjologicznych należy wymienić co najmniej trzy: anomię, apatię oraz atomię. Anomia oznacza dezintegrację więzi społecznych; apatia - znieczulice moralną; atomia - to, że w ponowoczesnych społeczeństwach większość woli żyć samej lub samemu i na własne konto, zapoznając myślenie w kategoriach dobra wspólnego. Jedyną rzeczą, uznawaną za wartościowa, okazuje się indywidualna korzyść. Wyłania się stąd wniosek, że aksjologia ponowoczesności, którą należy identyfikować z terminem negaksjologia, jest wewnętrznie ukierunkowana na promocję samotności jako kluczowej wartości.

\section{Summary}

\section{Negaxiologies of the public sphere. Social anomie, apathy and atomy - in the circle of the mono(seo)cracy}

\section{Keywords}

Negaxiology; public sphere; anomie; apathy; atomy; loneliness; monoseocrasy; egotism; narcissism; individualism; individual and public morality; postmodernity

In this paper I concern a phenomenon of negaxiologies characteristic for the postmodern epoch. It means some negative axiologies or axiologies of negative values. Among them it can be distinguished a lot of methods, approaches and 
tendencies. The part of them is more detailed, the other one more general. To the detailed negaxiological strategies belong: commercialism, consumerism, thinking only in an economic way, mercantile system, financial capitalism, hedonitrophism, competitivism, creativism, innovationism, the pressure on effectiveness, expansionism, individualism, rankingaphilia, certificataholism, professionalism, panactivism, the law inflation, amoral familism, the tendency to creating a positive image. Among the more general negaxiological approaches it should be mentioned at least three: anomie, apathy, atomy. Anomie means the disintegration of social bonds; apathy - the moral insensitivity; atomy - that in postmodern societies everyone prefers living alone without thinking about such categories like the common good. The only thing which is positively regarded is someone's individual benefit. It leads us to the conclusion that the postmodern axiology, which can be identified with the term negaxiology, is immanently oriented at promotion of loneliness as a key value.

\section{Bibliografia}

Badiou A., Etyka, Przewodnik Krytyki Politycznej, przeł. P. Mościcki, t. 13, Wydawnictwo Krytyki Politycznej, Warszawa 2009.

Baran B., Postmodernizm, Wydawnictwo inter esse, Kraków 1992.

Bauman Z., Ponowoczesność jako źródło cierpień, Wydawnictwo Sic!, Warszawa 2000.

Beck U., Beck-Gernsheim E., Individualization and "precarious freedom". Perspectives and controversies of a subject-oriented sociology, w: Detraditionalization. Critical Reflections on Authority and Identity, red. P. Heelas, S. Lash, P. Morris, Blackwell Publishers, Oxford 1996.

Cavalcante Schuback M. Sá, Pochwała nicości. Eseje o hermeneutyce filozoficznej, z j. szwedzkiego przeł. L. Neuger, Wydawnictwo UJ, Kraków 2008.

Chollet M., Tyrania rzeczywistości, przeł. A. Dwulit, Instytut Wydawniczy Książka i Prasa, Warszawa 2013.

Dahrendorf R., Life Chances. Approaches to social and political theory, University of Chicago Press, Chicago 1979.

Dembiński P. H., Finanse po zawale. Od euforii finansowej do gospodarczego ładu, przeł. Ł. Komuda, Wydawnictwo Studio Emka, Warszawa 2011.

Elias N., Społeczeństwo jednostek, przeł. J. Stawiński, red. nauk. i przedm. do wyd. pol. M. Marody, Biblioteka Socjologiczna, Wydawnictwo Naukowe PWN, Warszawa 2008.

Fromm E., Niech się stanie człowiek. Z psychologii etyki, przeł. R. Saciuk, Wydawnictwo Naukowe PWN, Warszawa-Wrocław 1999.

Fukuyama F., Koniec człowieka. Konsekwencje rewolucji biotechnologicznej, przeł. B. Pietrzyk, Wydawnictwo Znak, Kraków 2004.

Gumuła W., Zjawisko finansjalizacji, „Znak” czerwiec 2015, nr 721, s. 13-19.

Kołakowski L., Cywilizacja na ławie oskarżonych, w: O kryzysie, Rozmowy w Castel Gandolfo 1985, t. 2, przygot. i przedm. opatrzył K. Michalski, 
przeł. A. Kluba, Instytut Nauk o Człowieku, Res Publica, Warszawa 1990.

Kruszelnicki M., Drogi francuskiej heterologii, Wydawnictwo Naukowe Dolnośląskiej Szkoły Wyższej, Wrocław 2008.

Księżyk M., Źródła i ekonomiczne skutki kryzysów finansowych, „Nierówności Społeczne a Wzrost Gospodarczy" 2013, nr 30.

Marody M., Giza-Poleszczuk A., Przemiany więzi społecznych. Zarys teorii zmiany społecznej, Wydawnictwo Naukowe Scholar, Warszawa 2004.

Mayer H., Odmieńcy, przeł. A. Kryczyńska, Warszawskie Wydawnictwo Literackie Muza, Warszawa 2005.

Messyasz K., Między wspólnota położenia a jednościa pokoleniowa, „Władza Sądzenia" 2014, nr 3: Radykalny inkluzywizm. Orygenes zamiast Schmitta, red. K. Kubala, K. Nawratek, s. 79-97.

Ortega y Gasset J., Człowiek i ludzie, przeł. H. Woźniakowski, w: idem, Bunt mas inne pisma socjologiczne, PWN, Warszawa 1982.

Ortega y Gasset J., Dehumanizacja sztuki i inne eseje, przeł. P. Niklewicz, Czytelnik, Warszawa 1980.

Ortega y Gasset J., Medytacje o „Don Kichocie”, przeł. J. Wojcieszak, Warszawskie Wydawnictwo Literackie Muza, Warszawa 2008.

Perkowska H., Postmodernizm a metafizyka, Wydawnictwo Naukowe Scholar, Warszawa 2003.

Plessner H., Granice wspólnoty. Krytyka radykalizmu społecznego, przeł. J. Merecki, Oficyna Naukowa, Warszawa 2008.

Ratajczak M., Ekonomia i edukacja ekonomiczna w dobie finansyzacji gospodarki, s. 3, http://www.pte.pl/kongres/referaty/Ratajczak\%20M/Ratajczak\%20 M.\%20-\%20Ekonomia\%20i\%20edukacja\%20ekonomiczna\%20w\%20 dobie\%20finansyzacji\%20gospodarki.pdf (dostęp: 02.05.2014).

Ratajczak M., Finansyzacja gospodarki, „Ekonomista” 2012, nr 3, s. 281-302.

Renaut A., Era jednostki. Przyczynek do historii podmiotowości, przeł. D. Leszczyński, Zakład Narodowy im. Ossolińskich Wydawnictwo, Wrocław-Warszawa-Kraków 2001.

Ricoeur P., O sobie samym jako innym, przeł. B. Chełstowski, Wydawnictwo Naukowe PWN, Warszawa 2005.

Ricoeur P., What Is a Text? Explanation and Understanding, w: A Ricoeurs Reader: Reflection and Imagination, red. M.J. Valdés, New York-London-Toronto-Sydney-Tokyo-Singapore 1991.

Riesman D., Samotny tłum, przekł. oraz wstęp do wyd. pol. J. Strzelecki, Wydawnictwo Vis-à-vis/Etiuda, Kraków 2011.

Rougemont D. de, Udział Diabła, przeł. A. Frybes, Wydawnictwo Wodnika, Warszawa 1992.

Sloterdijk P., Kryształowy patac. O filozoficzna teorie globalizacji, przeł. B. Cymbrowski, Wydawnictwo Krytyki Politycznej, Warszawa 2011.

Taylor Ch., Źródła podmiotowości. Narodziny tożsamości nowoczesnej, przeł. M. Gruszczyński et al., oprac. T. Gadacz, Wydawnictwo Naukowe PWN, Warszawa 2001.

Toffler A., Ekospazm, przeł. E. Szymańska, Czytelnik, Warszawa 1977. 
Waldenfels B., Podstawowe motywy fenomenologii obcego, przeł. J. Sidorek, Oficyna Naukowa, Warszawa 2009.

Zagubiona rzeczywistość - rozmowa J. Żakowskiego, „Polityka” 2012, nr 5, s. 21-23; wersja elektroniczna: http://www.polityka.pl/tygodnik polityka/swiat/1523889,1,wywiad-zakowski-i-dembinski-o-recep cie-na-kryzys-cz-i.read oraz http://www.polityka.pl/tygodnikpolityka/ swiat/1523933,1, wywiad-zakowski-i-dembinski-o-recepcie-nakryzys-cz-ii.read (dostęp: 04.03.2014.).

Zdrenka M.T., Pewien kłopot z intersubiektywnościq wartości. Przyczynek do refleksji o negatywach, czyli o ogniskowaniu się negatywnych skojarzeń wartościujacych, w: Intersubiektywność, red. nauk. P. Makowski, TAiWPN Universitas, Kraków 2012. 